UDC: $159.922 .76-053.6$

DOI: https://doi.org/10.24195/2414-4665-2017-3-8

\author{
Anastasiia Mukhina, \\ PhD (Candidate of Psychological Sciences), associate professor, \\ Department of Defectology and Psychological Correction, \\ Luhansk Taras Shevchenko National University, \\ 1, Gogolia Square, Starobilsk, Ukraine
}

\title{
AWARENESS OF PHYSIOLOGICAL DIFFERENTIATION AND FUNCTIONAL PECULIARITIES OF MEN AND WOMEN IN MENTALLY RETARDED ADOLESCENT GIRLS
}

The paper is focused on studying the peculiarities of the process of gender and gender-role identity formation in mentally retarded adolescent girls. The summative experiment, which involved organised talk and projective technique "Drawing one's own and opposite sex", was used to identify the level of their awareness of differential distinctions between men and women, their functional peculiarities and the impact of gender identity on social expectations and behaviour.

Keywords: gender, role, identity, physiological peculiarities, masculinity, feminity.

\section{Introduction}

The formation of gender role begins with the differentiation of physiological parameters. Individual's gender-role behaviour depends on his/her perception of the body and the understanding of its functioning. This behaviour is responsible for reproductive function, social role of men and women in the society.

Gender awareness aspects are still understudied in psychology for special needs. It is well-known that mentally retarded children are not able to form standards and rules of social behaviour as well as moral principles and analysis of their deeds independently (V. Bodnar, D. Isaiev, V. Kovalova, V. Kuzmina, K. Lebedynska, V. Synov, O. Khokhlina), which makes their socialisation impossible. Disorders in social adaptation of mentally retarded adolescents can be affected by the deviations in the formation of their gender identity and acquisition of gender roles (V. Harbuzov, E. Eidemiller, D. Isaiev, V. Kahan, M. Pishchek, H. Poppe, L. Shypitsyna and others) [3].

Ch. Kozhaliieva points out at mentally retarded adolescents' independence in creating their role models; however, there are more opportunities for reflexive analysis at the age of 14-15. Gender-role identity of mentally retarded children was studied by $\mathrm{M}$. Pishchek who emphasised the absence of preconditions for gender-role identity formation and inconsistency of gender awareness formation (a girl - an adolescent girl - a woman). The researcher distinguished another problem: a mentally retarded child always remains a child, especially for his/her parents, which causes gender-role identity disorders [4]. L. Shypitsyna studied the features of gender-role identity in mentally retarded girls who are brought up in residential settings. She found however that gender-role identity of girls with mild mental retardation who are brought up in families, attend special needs school and have opportunities for socialisation is underinvestigated [5]. The issues of gender socialisation and gender-role awareness of mentally retarded adolescents were studied by N. Zaihraieva and I. Korobeinik who observed the quality of mentally retarded adolescents' awareness of their gender roles and factors affecting them [7]. V. Levytskyi investigated the features of gender-role education of pupils attending primary special needs school. He distinguished cognitive (knowledge), emotional (attitude) and behavioural (gender-role behaviour) components of gender-role identity [3].

Social expectations of women are stricter compared to those of men; it is quite difficult to understand corresponding behavioural patterns under conditions of the current transformations of gender roles. The peculiarities of women's consciousness were studied by O. Valieieva (psychological peculiarities of a girl's attitude to herself as a future woman), O. Laktionov (value system, experience of a new woman), V. Bondarovska, I. Shlapakova (woman's gender-role identity), I. Zherebkina (the phenomenon of female corporeality, female body representation), T. Hurlieva (adolescent girls' age issues and prevention of educating difficulties). Genderrole identity is related to somatic, psychological and social well-being (D. Isaiev, V. Kahan, I. Kon, O. Kocharian, R. Stoller), specifies the features of sexual and marital relations (A. Kotsar, N. Khamitov) and professional fulfilment (G. Hofstede).

The research works of international scientists demonstrate that psychosexual development of mentally retarded and mentally healthy individuals is generally similar, though they do not coincide in time and are qualitatively different. Mentally retarded individuals as well as mentally healthy people have their own needs, though their hierarchy, intensity and way of demonstrations are different, which depends on degree and structure of intellectual disability.

\section{Methodology}

The scope of the study involved 116 mentally retarded and 112 mentally healthy girls of 5-10 grades. The girls were divided into two groups according to their age, and each group was divided into two more groups depending on the level of the girl's intelligence. All of the study participants live in families: a great number of them 
have no father, some of them live in nuclear families or with grandparents; there were families with one child, two and more children. The following methods were used: observation, conversation, questionnaire, analysis of works, qualitative and quantitative analysis of the obtained empirical data and their statistical processing (Pearson's chi-squared test, Mann-Whitney U test, Kruskal-Wallis test, and Spearmen's rank correlation). The study complies with the comparative principle, the principle of integrity, consistency and dynamic personality research. Also we used the information about the influence of sex hormones on physiological parameters (2D:4D ratio, D. Putz, S. Gaulin) [2].

\section{Discussion}

The methodology "The picture of a dressed/undressed person of the same and opposite sexes" involved the elements of Draw-a-Person test, which made it possible to investigate the cognitive component of gender-role identity. Physiological sex differentiation (primary and secondary sexual characteristics), hairdo, clothes, accessories as additional elements of femininity and masculinity were taken into account. The girls were interviewed after drawing the pictures. In order to receive more detailed information, we used a modified inventory for children developed by N. Oleksandrova, which was intended for identifying the level of knowledge of psychophysiological distinctions between men and women: reproduction, body build, capability for raping (sexual assault), father's role in childbirth, tertiary sexual characteristics of men and women; we also registered shyness, interest, indifference or negative attitude to sex-related issues in general, to male and female figures. It is worth noting that regardless of their age mentally retarded girls smiled embarrassedly and found it uncomfortable to draw such things, while their mentally healthy age-mates felt embarrassed only at the age of 11-12. The more detailed and precise the pictures of male and female figures were, the more embarrassed and ashamed of their pictures mentally retarded girls felt. Thus, higher level of intelligence determines more differentiated emotional reactions regarding oneself and one's body, more developed shyness and morality.

Mentally retarded girls of 11-13 years depicted male and female figures almost in the same way $(71.2 \%)$, there were no differences in depicting the figures dressed and undressed $(67.8 \%)$; some of the girls were not able to draw either male or female figures at all: they could only draw "stick figures" or sketches, where the body and limbs were depicted as five straight lines. $28.8 \%$ of mentally retarded girls aged 11-13 drew women wearing high heels, with accentuated eyelashes and lips, having buttons, flounces and decorative patterns on their clothes, belts, jewellery. Naked bodies were depicted randomly by $22 \%$ of the girls; the rest of the girls drew dressed and undressed figures in the same way or depicted only upper bodies different from each other in terms of body parts and organs, while the lower bodies remained the same. It indicates poorly developed abstraction, inability to depict naked human body, especially male figure (78\%). As for distinctions between male and female figures, the girls drew long hair and different sexual organs (83\%), accessories and clothes (16.9\%).

Most mentally retarded girls aged 14-16 years depicted male and female figures imprecisely and schematically $(61.4 \%)$. Male and female figures differed from each other by hair length, clothes and sexual organs (70.2\%), accessories were pictured by $40.3 \%$ of the girls. None of the girls marked distinctions between male and female body proportions (curvy hips and slim waist peculiar to women). Some of the girls pictured rounded stomach demonstrating reproduction as the main female function (7\%). Both male and female bodies were depicted schematically: breasts as two circles or one circle divided in two, sexual organs were drawn carelessly (85.9\%), incorrectly, artificially, over the clothes $(65 \%)$. It should be noted that at this age mentally retarded girls showed more shyness and embarrassment while drawing the pictures, some of them found it uncomfortable to picture sexual organs, though they drew breasts. It is important to mention that male figure was always smaller than female if a woman was head of the family or it was a father-absent family.

The girls were interviewed before and after drawing. The test conductor intended to find out psychophysiological and gender differences between men and women. For example, mentally retarded girls aged 11-13 mentioned some differences in appearance: shoe size, colour of the clothes, height, etc. as well as some physiological differences: women's periods, different structure of organs, etc. Mentally retarded girls of 14-16 years did not mention inner characteristics of men and women in their answers, but spoke about physiological parameters, reproduction, men's strength and women's beauty.

Mentally healthy girls of 11-13 years depicted ornaments, rouches on women's clothes, long hair with a hairdo; lips and eyelashes were bigger than men's and were pictured more thoroughly $(85.4 \%)$. Undressed figures were drawn correctly by almost all the study participants; the girls demonstrated shyness, which resulted in quick and careless drawing of the naked bodies (88.7\%). 11-13-yearold girls could not depict secondary sexual characteristics $(77.4 \%)$ and were not familiar enough with tertiary (gender) sexual characteristics (42\%), especially with those of men. 14-16-year-old girls could draw male and female sexual organs precisely, they depicted anatomic features of men's and women's bodies and tried to picture abdominal and other muscles, broad shoulders, aerobicised breasts, narrow hips of men $(88.7 \%)$. It is explained by studying the course of human anatomy, girls' observation over their bodies during puberty period and increased interest in sexual and personal relationships. Consequently, there can be observed the increase of the level of cognitive component of gender-role identification. The girls explained the features of anatomical organisation by reproductive function and the fact that female body is beautiful and meant for attracting men, while male body is meant for labour and defending women. 
Mentally retarded girls aged 11-13 years considered human appearance as the basic difference between people, namely: height, weight, hair length, make-up. Mentally healthy girls of the same age thought that men and women also differ by personality traits: women are capable of making concessions, they are tender, faithful, trustful, kind-hearted, calm, appealing, loving children and have a developed sense of duty; men are aggressive, bossy, independent, unpredictable, and risk-prone. Mentally retarded girls of 14-16 years were also bad at distinguishing men from women. Some of them refused to characterise men at all explaining it by the fact that girls should talk about women, and it was up to boys to characterise men. Mentally healthy girls of the same age added vivid examples from their own or their friends'/relatives' lives, characteristics of women's and men's roles; mentioned corresponding professional interests and differentiated household responsibilities.

As for the development of the visions of male and female bodies, the scope of this knowledge in mentally healthy girls is increasing with age (the mean score rises from 9.4 to 14.3). At the same time, it increases insignificantly among mentally healthy girls ( 2 to 4 scores). It can be explained by the fact that discussing these issues with mentally retarded girls is aimed mostly at prevention and intimidation.

Also, we used $N$. Oleksandrova's methodology, which was aimed at assessing children's/adolescents' awareness of physiological parameters, reproduction, sexual assault, pregnancy, father's role in childbirth. Mentally retarded girls aged 11-13 could not say anything about physiological distinctions between men and women - in most cases they only mentioned different appearance; 14-16-year-old girls with mental retardation were ashamed to answer these questions, because they considered themselves to be "not adult enough" for them $(70.2 \%)$. The girls answered that a sexual assault was "something between a woman and a man... when he is undressing her and getting undressed himself..." or "when one will not be able to have children anymore", "a sexual assault ends with a murder" $(56.1 \%)$. They could not differentiate a sexual intercourse from a sexual assault. Some of them told that a sexual assault was sex without love. 11-13-year-old girls said that it was a very bad thing but could not explain what it was exactly $(84.7 \%)$. Besides, the girls with mental retardation had

\section{ЛІТЕРАТУРА}

1. Вихователю про психологію та поведінку сексуального розвитку дитини: Науково-методичний збірник / За ред.Т. В. Говорун.-К.: Інститут змісту і методів навчання, 1996. - 168c.

2. Заиграева Н. В. Гендерная социализация и полоролевые представления подростков с интеллектуальной недостачностью / Н. В. Заиграева // Дефектология. -2007 . - №2. - С. 46-51.

3. Нугаева О. Г. Определение понятия «нарушения половой идентификации» / О. Г. Нугаева // Со- poor knowledge of the issues associated with pregnancy prevention. Some of them knew about the existence of contraceptives, but all of the girls had no idea about their role, purpose and use. A great number of the girls thought that the partners did not need to use any medical contraceptives, because they could regulate this process themselves. Some of the girls mentioned pills and condoms as pregnancy prevention methods, though they considered the pills to be bad for health, and condoms - unreliable as they could "come off", "get stuck inside" or "be off size" (71.9\%). As for father's role in childbirth, 11-13-year-old girls answered that he was meant for "bringing up children and punishing them", "earning money" (92.9\%). When asked about pregnancy, most of the girls attending special needs school answered that it was the period "when a woman's stomach became big and rounded", "when a woman was going to have a baby", etc. Mentally healthy girls of the same age gave more detailed answers to these questions and they felt obviously less ashamed. Mentally retarded girls of 14-16 years gave the same answers as those of 11-13 years, their answers were mostly far from the truth. However, they were not so much ashamed to discuss physiological characteristics of men and women. Mentally healthy girls gave detailed answers to all the questions and almost all of them were correct.

The findings of the research demonstrate that a great number of mentally retarded girls, especially of junior adolescent age, have poor knowledge of the issues related to sexes, sexual maturation, pregnancy and childbirth, parents' roles in a family. Sexual education is quite important nowadays, therefore, if most mentally retarded adolescents are familiar with the above-mentioned issues, the number of early abortions, unwanted pregnancies and sexually transmitted diseases will reduce significantly.

\section{Conclusions}

The review of the results shows that mentally retarded adolescent girls are generally characterised by acceptance of their role and the low level of awareness of psychophysiological features of men and women; inability to differentiate male and female traits; careless attitude towards themselves, their bodies and appearance; negative attitude towards the opposite sex (father, boys), sexual activity; lack of socially approved models of female behaviour. Further research will cover the aspects of gender-role behaviour of adolescent girls and creating the programme for the formation of their gender prototypes.

вершенствование коррекционно-развивающей работы с детьми в специальных учреждениях / Под ред. В. В. Коркунова; Урал. гос. пед. ун-т; Ин-т спец. обря. - Екатеринбург, 2002. - С. 23-31.

4. Синьов В. М. Психологія розумово відсталої дитини: підручник / В. М. Синьов, М. П. Матвєєва, О. П. Хохліна. - К. : Знання, 2008. - 359 с.

5. Шипицына Л. М. «Необучаемый» ребенок в семье и обществе: учеб.пособие для учит., студ пед 
инст по спец. «Дефектология» / Л. М. Шипицына. М. : СПб., Речь, 2005. - 486.

6. Носов Н. Н. Формирование неадекватной самоидентичности и агрессивность / Н. Н. Носов // Воп-

\section{REFERENCES}

1. Hovorun, T. V. (Ed.). (1996). Vykhovateliu pro psykholohiiu ta povedinku seksualnoho rozvytku dytyny [About psychology and behaviour of child's sexual development]. Kyiv: Instytut zmistu i metodiv navchannia [in Ukrainian].

2. Zaigrayeva, N. V. (2007). Gendernaya sotsializatsiya i polorolevye predstavleniya podrostkov s intellektualnoy nedostachnostyu [Gender socialization and gender-role awareness of adolescents with mental retardation]. Defektologiya - Defectology, 2, 46-51 [in Russian].

3. Nugayeva, O. G. (2002). Opredeleniye ponyatiya «narusheniya polovoi identifikatsii» [Definition of the concept "sex-role identificantion"]. Sovershenstvovaniye korrektsionno-razvivayuschey raboty s detmi $v$ spetsialnykh uchrezhdeniyakh - Improvement of correctional and developmental work with children attending special needs school. V. Korkunov (Ed.). Yekaterinburg [in Russian]. росы психического здоровья детей и подростков/ 2003 (3), №1. - М. : Просвещение, 1991. - 127c.

7. Романова В. Г. Особливості статеворольових стереотипів підлітків / В. Г. Романова // Практична психологія та соціальна робота. - 2000. - № 8. - С. 39-43.

4. Synov, V. M., Matvieieva, M. P., \& Khokhlina, O. P. (2008). Psykholohiia rozumovo vidstaloi dytyny: Pidruchnyk [Psychology of mentally retarded children: Textbook]. Kyiv: Znannia [in Ukrainian].

5. Shipitsyna, L. M. (2005). «Neobuchaemyi» rebenok v semye $i$ obschestve [Learning-disabled children in families and society]. Moscow; St. Petersburg: Rech [in Russian].

6. Nosov, N. N. (1991). Formirovanie neadekvatnoy samoidentichnosti i agressivnost [The formation of inadequate self-identity and aggressiveness]. Voprosy psikhicheskogo zdorovya detey i podrostkov - Issues of mental health of children and adolescents, 1 . Prosveshchenie [in Russian].

7. Romanova, V. G. (2000). Osoblyvosti statevorolovykh stereotipiv pidlitkiv [Peculiarities of adolescents' gender-role stereotypes]. Praktychna psykholohiia ta sotsialna robota - Practical psychology and social work, 8, 39-43 [in Ukrainian].

Анастасія Юрї̈вна Мухіна, кандидат психологічних наук, доцент кафедри дефектології та психологічної корекції, Луганський начіональний університет імені Тараса Шевченка, пл. Гоголя, 1, м. Старобільськ, Україна

\section{УЯВЛЕННЯ ПРО ФІЗІОЛОГІЧНУ ДИФЕРЕНЦІАЦЮЮ ТА ФУНКЦІОНАЛЬНІ ОСОБЛИВОСТІ ЧОЛОВІКІВ І ЖІНОК У ДІВЧАТ ПІДЛІТКОВОГО ВІКУ 3 ПОРУШЕННЯМИ ІНТЕЛЕКТУ}

У статті презентовано результати констатуючого експерименту щодо сформованості когнітивного компоненту знань стосовно диференціації фізіологічних і функціональних особливостей чоловіків і жінок у дівчат підліткового віку з розумовою відсталістю. Проаналізовано та порівняно результати двох вікових груп дівчат з розумовою відсталістю, а саме молодшого підліткового віку (11-13 років) і старшого підліткового віку (14-16 років) 3 метою встановлення наявності або відсутності динаміки формування уявлень про свою та протилежну стать. За результатами проведеного дослідження було виявлено низький рівень знань щодо будови тіла, диференційних ознак маскулінності та фемінності. Дівчата характеризувалися сформованістю хибних уявлень про статевий акт, вагітність та згвалтування. Вони не вважають за необхідне користуватися засобами контрацепції і мають міфічні уявлення про їхні функціональні особливості. Також з'ясовано, що впродовж всього підліткового віку дівчатами з розумовою відсталістю не диференціюються внутрішні якості чоловіків і жінок. Знання про фізіологічні та психологічні якості чоловіків у розумово відсталих дівчат значно нижче, ніж знання про жінок. Дуже часто відношення до хлопців і чоловіків або недиференційоване або негативне, що пояснюється відсутністю повної родини у багатьох дівчат із розумовою відсталістю, а також пояснювально-залякувальним характером бесід, що проводять вчителі у школі. Встановлено, що чим вище рівень інтелектуального розвитку дівчат, тим більш диференційовані емоційні реакції щодо себе й свого тіла, розвинена сором'язливість і моральність. Аналіз отриманих результатів показує, що для розумово відсталих дівчат-підлітків загалом характерне прийняття свого тіла та своєї ролі. Однак, низький рівень ознайомлення з психофізіологічними особливостями жіночої і чоловічої статі, диференціації жіночих і чоловічих рис не дає можливості повною мірою освоїти процес ідентифікації, що зумовлює ряд проблем: недбайливе ставлення до себе, до свого тіла й зовнішності; негативне ставлення до осіб протилежної статі (батько, хлопці), до статевого життя; відсутність у поведінці соціально схвалюваних моделей жіночої поведінки.

Ключові слова: стать, роль, ідентичність, фізіологічні особливості, маскулінність, фемінність.

Reviewed by Doctor of Psychology, prof. Yu. Bystrova

Submitted on February, 15, 2017 